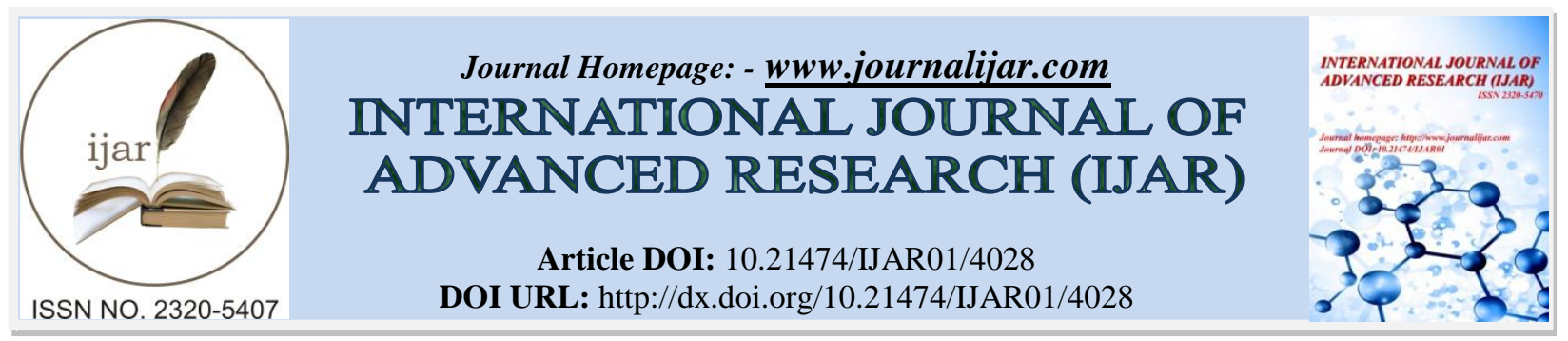

RESEARCH ARTICLE

\title{
KNOWLEDGE, ATTITUDE AND PRACTICE OF DENTAL STUDENTS REGARDING HEPATITIS INFECTIONS.
}

Archana Venugopal, T.N. Uma Maheswari.

\section{Manuscript Info}

Manuscript History

Received: 26 February 2017

Final Accepted: 21 March 2017

Published: April 2017

\begin{abstract}
Hepatitis is an infection widely haunting the health care workers especially dentist. It is essential for the dental health care providers to have good knowledge about the hepatitis infection and also put them into practice. Current study reveals the shortcomings in the practice and attitude among the dental student. There by throwing light on the field that needs improvement to prevent the spread of infection from one patient to another, from patient to the dentist and vice versa.
\end{abstract}

Copy Right, IJAR, 2017,. All rights reserved.

\section{Introduction:-}

Hepatitis is a viral infection that affects the liver and can cause both acute and chronic diseases. According to WHO, two billion people (one-third of the world population) have evidence of hepatitis B virus (HBV) infection in blood and 360 million are chronic carriers and at risk of liver disease $(1,2)$.

Vaccination is the most effective measure to reduce the incidence of hepatitis B. In 1991, the WHO recommended the integration of universal hepatitis B vaccination by 1997 to prevent and control on a global scale HBV infection and its long-term, manifestation(3). There are also complications following Hepatitis B vaccination. There can be sudden infant death syndrome, multiple sclerosis, chronic fatigue syndrome, idiopathic thrombocytopenic purpura, vasculititis optic neuritis, anaphylaxis, systemic lupus erythematosus, lichen planus and neuro-muscular disorder(4). It has been estimated that $14.4 \%$ and $1.4 \%$ of hospital workers are infected with HBV and HCV, respectively(5). However good knowledge about the dental consideration and precautionary measures to protect skin and mucous membrane of the health care professionals is important.

The virus is transmitted via the blood and body fluids of infected person, so it is an important occupational hazard among the dentist Hence the knowledge about the infection, the attitude towards the infection and the practice followed to prevent it s an important concern.

\section{Materials and methods:-}

A questionnaire was formulated, with 15 questions to assess each of knowledge, attitude and practice among dental students. A convenient sampling method was used. 150 questionnaires were distributed among the 50 students each from Group A (final year UG students),Group B( Residents) and Group C(PG students). Out of which 122 questionnaires were returned with complete answers. It was then evaluated in each of those aspects of knowledge, attitude and practice among the 3 groups.

Corresponding Author:- Archana Venugopal, T.N. Uma Maheswari. 
Statistical Analysis:-

ANOVA was done to assess the difference between the three groups regarding their knowledge attitude and practice towards hepatitis infection.

Table I:- Knowledge Attitude And Practice Questionnaire For Hepatitis Infection Used In The Study.

\begin{tabular}{|c|c|c|c|}
\hline 1 & Hepatitis B is a .............infection? & 9 & $\begin{array}{l}\text { Is there active immunization available for } \\
\text { Hepatitis B? }\end{array}$ \\
\hline 2 & $\begin{array}{l}\text { Where is the highest concentration of hepatitis B } \\
\text { ? }\end{array}$ & 10 & $\begin{array}{l}\text { When should the booster doses be provided for } \\
\text { Hepatitis B? }\end{array}$ \\
\hline 3 & What is the oral manifestation of the disease? & 11 & $\begin{array}{l}\text { Do you sterilize your instruments according to } \\
\text { the sterilization protocol in between patients? }\end{array}$ \\
\hline 4 & $\begin{array}{l}\text { Are there any vaccination available for hepatitis } \\
\text { B infection? }\end{array}$ & 12 & $\begin{array}{l}\text { Have you ever been pricked accidentally by a } \\
\text { needle used for a patient? }\end{array}$ \\
\hline 5 & $\begin{array}{l}\text { What is the incubation period for hepatitis B } \\
\text { infection? }\end{array}$ & 13 & $\begin{array}{l}\text { Do you take proper history of patients before } \\
\text { starting the treatment? }\end{array}$ \\
\hline 6 & $\begin{array}{l}\text { Can hepatitis } B \text { infection be self cured by the } \\
\text { body? }\end{array}$ & 14 & $\begin{array}{l}\text { Do you wear a double glove and double ask in } \\
\text { case you happen to treat a hepatitis B infected } \\
\text { patient? }\end{array}$ \\
\hline 7 & $\begin{array}{l}\text { Have you completed the course of vaccination } \\
\text { for hepatitis B infection? }\end{array}$ & 15 & $\begin{array}{l}\text { The first thing you do if you happen to } \\
\text { accidentally prick by a needle used for a } \\
\text { patient, you carefully wash the wound without } \\
\text { rubbing it hard for several minutes with soap. } \\
\text { Using a disinfectant of established efficacy, or } \\
\text { apply pressure below the wound induce } \\
\text { bleeding? }\end{array}$ \\
\hline 8 & What is the vaccination protocol for hepatitis B? & & \\
\hline
\end{tabular}

\section{Results:-}

Though Group C were found to have better knowledge, attitude and practice than the Group A and Group B, there was no significant statistical difference between the groups

Figure I:- Percentage wise distribution of answers to the questionnaire by three different groups.

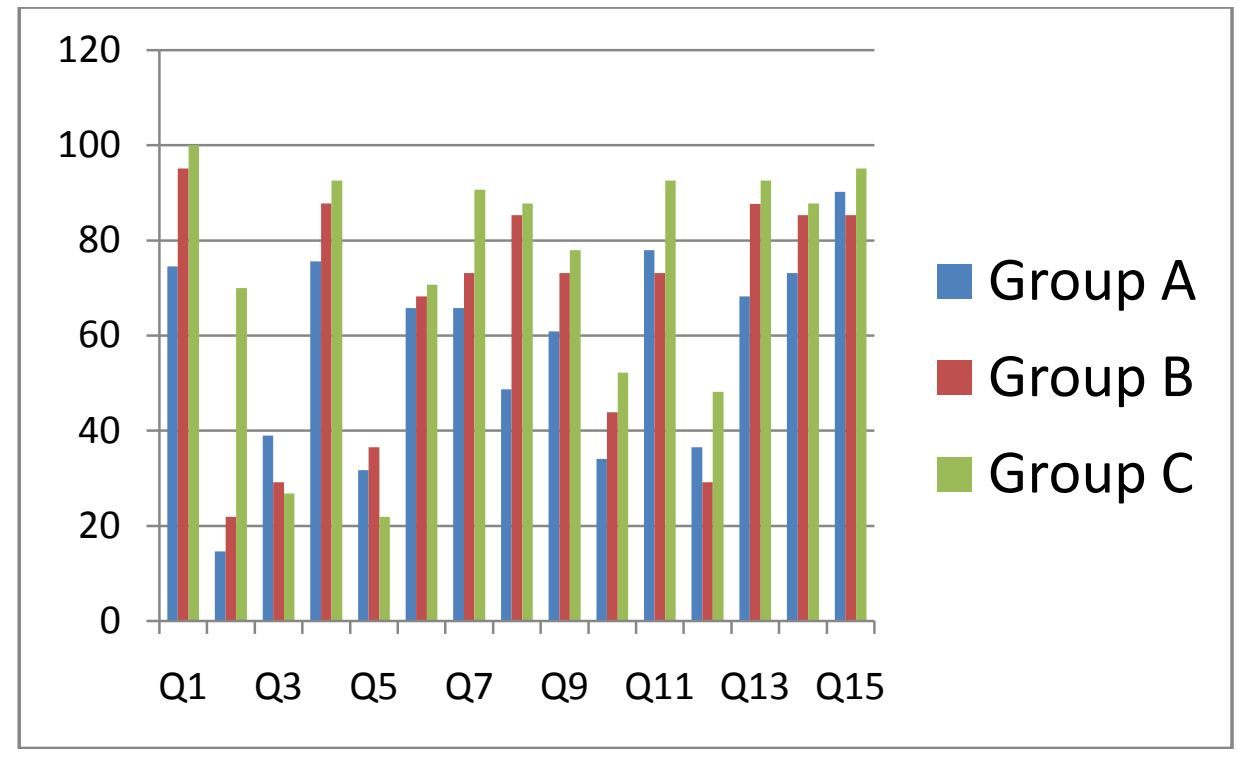


Table Ii:- Multiple Comparisons Between Groups.

\begin{tabular}{|l|l|l|l|l|l|l|}
\hline & & $\begin{array}{l}\text { MEAN } \\
\text { DIFFERENCE }\end{array}$ & $\begin{array}{l}\text { STD. } \\
\text { ERROR }\end{array}$ & SIG & \multicolumn{2}{l|}{$\begin{array}{l}\text { 95\%CONFIDENCE } \\
\text { INTERVAL }\end{array}$} \\
\hline & & & & & $\begin{array}{l}\text { LOWER } \\
\text { BOUND }\end{array}$ & $\begin{array}{l}\text { UPPER } \\
\text { BOUND }\end{array}$ \\
\hline GROUP A & GROUP B & $\mathbf{- 3 . 6 2 0 0}$ & $\mathbf{1 2 . 6 3}$ & $\mathbf{0 . 9 5 6}$ & $\mathbf{- 4 2 . 4 0 2 3}$ & $\mathbf{3 5 . 1 5 6}$ \\
\hline & GROUP C & $\mathbf{- 1 2 . 0 4 6}$ & $\mathbf{1 2 . 6 3}$ & $\mathbf{0 . 6 3 0}$ & $\mathbf{- 5 0 . 8 2 9}$ & $\mathbf{2 6 . 7 3 5 6}$ \\
\hline GROUP B & GROUP A & $\mathbf{3 . 6 2 0 0}$ & $\mathbf{1 2 . 6 3}$ & $\mathbf{0 . 9 5 6}$ & $\mathbf{3 5 . 1 6 3}$ & $\mathbf{4 2 . 4 0 2 -}$ \\
\hline & GROUP C & $\mathbf{- 8 . 4 2 6 6}$ & $\mathbf{1 2 . 6 3}$ & $\mathbf{0 . 7 9 0}$ & $\mathbf{- 4 7 . 2 0}$ & $\mathbf{3 0 . 3 5}$ \\
\hline GROUP C & GROUP A & $\mathbf{1 2 . 0 4 6 6}$ & $\mathbf{1 2 . 6 3}$ & $\mathbf{0 . 6 3 0}$ & $\mathbf{- 2 6 . 7 3}$ & $\mathbf{5 0 . 8 2}$ \\
\hline & GROUP B & $\mathbf{8 . 4 2 6 6 7}$ & $\mathbf{1 2 . 6 3}$ & $\mathbf{0 . 7 9 0}$ & $\mathbf{- 3 0 . 3 5 5}$ & $\mathbf{4 7 . 2 0}$ \\
\hline
\end{tabular}

\section{Discussion:-}

One study from Syria (7) demonstrates high number of medical students that are not vaccinated or not sure about their vaccination status, which puts them at a higher risk of being infected in the future. Another study conducted in Portuguese for workers of family health strategy programme, states only $66.1 \%$ were vaccinated, $52.5 \%$ received three doses, $30.4 \%$ verified immunization(8).

Despite the awareness of the basic medical sciences and the need for vaccination, before entering the clinics only $21 \%$ of the students have not completed the vaccination protocol. With the increase in the years of clinical practice and patient exposure there is an increase in the percentage of the vaccinated students. About $58.5 \%$ of students have been accidentally pricked by needle during practice but only $73.2 \%$ are aware of the active immunization available for hepatitis B and only $76 \%$ of them are aware of the booster doses for the vaccination. About $40.7 \%$ believe hepatitis B has no oral manifestation and hence are less capable of diagnosing or suspecting the infection and taking necessary precautions.

The increase in the years of clinical practice and specialization increases the knowledge attitude and practice of the dental students towards the control and prevention of the infection. Better knowledge attitude and practice among dental students can prevent Hepatitis B infection.

\section{Reference:-}

1. World Health Organization. Geneva, Switzerland: World Health Organization; 2000. [Last accessed on 2013 Dec 11]. Hepatitis B.(Fact sheet no. 204) from:http://www.who.int/mediacentre/factsheets/fs204/en/index.html .

2. World Health Organization. Hepatitis B vaccines. Wkly Epidemiol Rec. 2004;79:255-63. [PubMed]

3. World Health Organization. WHO expanded programme on immunisation. Global advisory group. Weekly Epidemiol Rec. 1992;3:6-11

4. Tarakji B, Ashok N, Alakeel R, Azzeghaibi S, Umair A, Darwish S, et al. Hepatitis B Vaccination and Associated Oral Manifestations: A Non-Systematic Review of Literature and Case Reports. Ann Med Health Sci Res. 2014;4(6):829-36.

5. Polish LB, Tong MJ, Co RL, Coleman PJ, Alter MJ. Risk factors for hepatitis C virus infection among health care personnel in a community hospital. Am J Infect Control 1993;21:196-200.

6. Borg MA. Hepatitis B transmission through blood and body fluids exposure of school personnel. Occup Med Oxf Engl. 2005 Mar;55(2):133-5.

7. Ibrahim N, Idris A. Hepatitis B Awareness among Medical Students and Their Vaccination Status at Syrian Private University. Hepat Res Treat. 2014;2014:131920.

8. Martins AME de BL, da Costa FM, Ferreira RC, Santos Neto PE dos, de Magalhaes TA, de Sá MAB, et al. Factors associated with immunization against Hepatitis B among workers of the Family Health Strategy Program. Rev Bras Enferm. 2015 Feb;68(1):77-84, 84-92. 